\title{
ЮВІЛЕї
}

DOI: $10.33402 / \mathrm{ukr} .2020-33-530-532$

\section{HONESTE VIVERE, ALTERUM NON LAEDERE, SUUM CUIQUE TRIBUERE}

«Чесно жити, не робити зла іншим, кожному віддавати належне» - саме цей принцип, який сформулював давньоримський правник та державний діяч Доміцій Ульпіан (Domitius Ulpianus), найвлучніше характеризує академіка Валерія Андрійовича Смолія як людину, як науковця, як колегу і як керівника.

Майже однолітки й обидва подоляни, ми різними з ним шляхами і з різницею у п’ять років (він раніше за мене) потрапили у «глухі» 1970-ті до тоді ще Інституту історії Академії наук (АН) України, де кожен кинув свій науковий якір, щоби більше не піднімати його...

Минали роки, захищалися дисертації, робилися успішні наукові кар'єри, народжувалися діти та книги, але довгий час через різницю у сфері наукових інтересів наші з Валерієм Андрійовичем шляхи й орбіти майже не перетиналися, окрім, як невимушено в коридорах інституту.

Буремні 90-ті принесли зміни не лише в долю України, що стала незалежною, Інституту - тепер вже історії України Національної академії наук (НАН) України, а й у наші з Валерієм Андрійовичем професійні й просто людські взаємини.

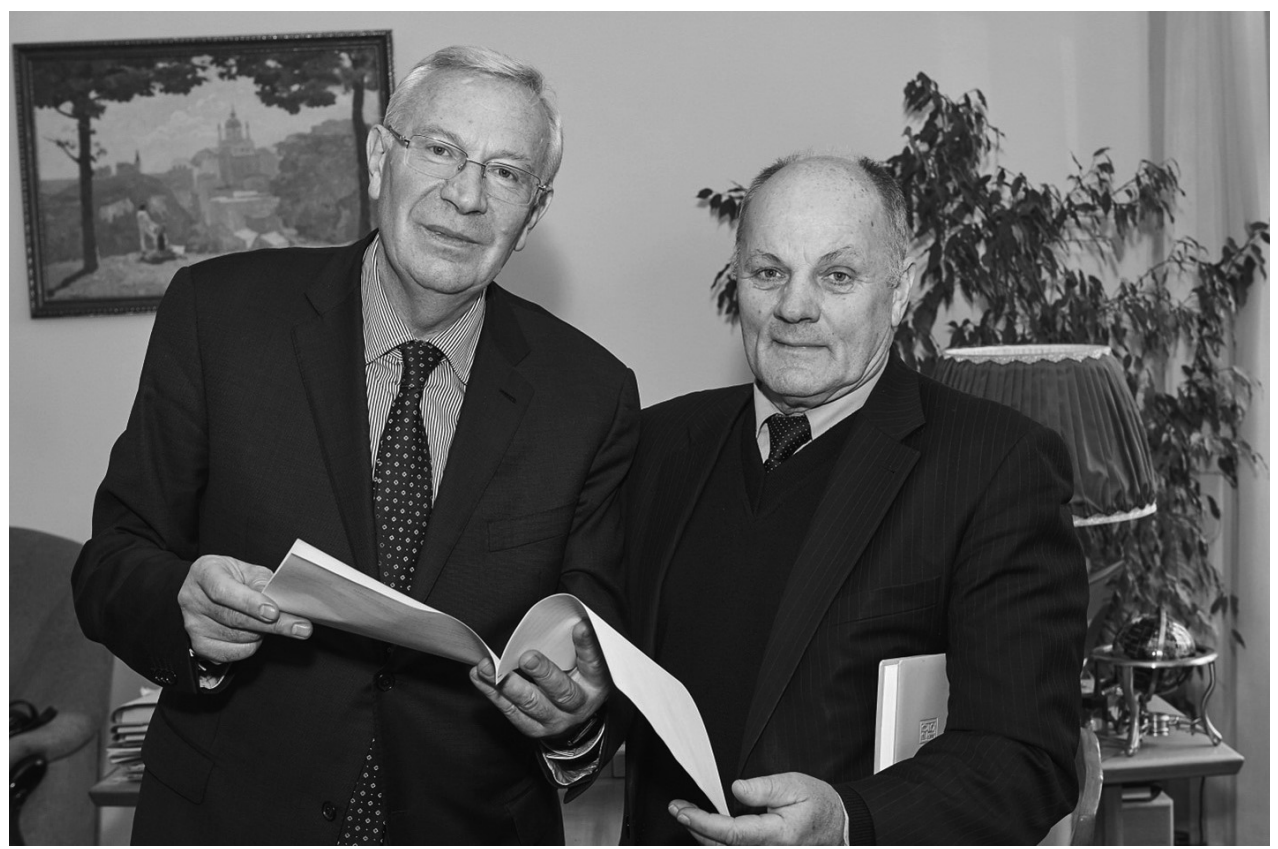

Академік В.А. Смолій (зліва) з членом-кореспондентом О.П. Реєнтом 
Ніколи не переставав дивуватися особливо тонкому відчуттю і мудрій проникливості покійного доброї пам'яті академіка Юрія Юрійовича Кондуфора, який, сам усвідомивши як вимогу часу необхідність передати штурвал інституту в інші, молодші та дужчі, руки, з-поміж багатьох претендентів зупинив вибір саме на Валерію Смолієві. Сьогодні це вже можна сказати, що останньому вдалося провести корабель Інституту історії України через усі шторми дев'яностих, нульових і десятих, оновивши його й не розбивши об скелі. Мав і маю за честь стояти поряд із Валерієм Андрійовичем у цій відповідальній та нелегкій місії з 1994 р. - спочатку на посаді виконувача обов'язки заступника директора з наукової роботи, а з 1996 р. - заступника директора з наукової роботи. Принагідно зауважу, що Валерій Андрійович, який незадовго переді мною обіймав цю ж посаду і добре розумів специфіку роботи на ній, виявив терплячість та надав необхідну допомогу новопризначеному, що тоді дозволило мені швидше увійти в курс справ і посадових обов'язків.

Конфуцію (孔子) приписують крилату фразу: «Не дай Боже вам жити в епоху змін». Просто жити... А керувати?! Нести відповідальність за установу та колектив, де кожен - особистість і в кожного свої життєві проблеми, а в інститутській касі, траплялося, місяцями лише спогади про гроші... А ще й окреслювати наукові обрії, досягати їх із колективом і мотивувати йти далі...

Опираючись на досвід багаторічного щоденного службового спілкування 3 Валерієм Андрійовичем, особливо хотілося би відзначити такі його риси, як дуже гостре відчуття нового й перспективного в напрямах досліджень, толерантність, вміння слухати i, що не менш важливо, чути співрозмовника, відсутність будь-якої зверхності й «забронзовілості» у ставленні до колег, певна мудра обережність в ухваленні управлінських і кадрових рішень («рубати з плеча», попри цілком природне для нього козакофільство, - не в його стилі), щире переймання долею колективу й намагання будь-що зберегти його.

Свої особисті зв’язки (наприклад, багаторічну дружбу з Володимиром Михайловичем Литвином) чи посадові можливості (перебування у 1997-1999 рр. на посаді віцепрем'єр-міністра України з гуманітарних питань) Валерій Андрійович завжди використовував в інтересах очолюваного Інституту історії України НАН України. Так, працюючи в уряді, йому вдалося в епоху тотального безгрошів'я «дотиснути» віцепрем’єра 3 економіки Сергія Леонідовича Тігіпка на виділення 100 тис. грн на перший за багато років ремонт приміщення Інституту історії.

Сповна особисто реалізувавшись як науковець i, по суті, створивши власну школу медієвістики та новістики, Валерій Андрійович виносив і дав старт у життя багатьом знаковим загальноінститутським колективним проєктам та виданням, місце найбільшої перлини серед яких, безумовно, по праву посідає фундаментальний 10-томний академічний - «Енциклопедія історії України».

Валерій Андрійович - ініціатор створення нової концепції української історії, основні положення якої відображено в низці колективних й авторських монографій, зокрема 15-томній серії «Україна крізь віки», відзначеній Державною премією України в галузі науки і техніки; серії біографічних нарисів «Особистість і доба». Під його керівництвом реалізовані такі масштабні проєкти, як «Уряди України у XX столітті: науково-документальне видання», «Нариси з історії дипломатії України», «Політичний терор і тероризм в Україні XIX-XX ст.», «Голод 1932-1933 років в Україні: причини та наслідки», «Україна і Росія в історичній ретроспективі: 
нариси в 3-х т.», «Україна - козацька держава. Ілюстрована історія українського козацтва у 5175 фотосвітлинах», «Історія українського селянства: нариси у 2 т.», «Історія українського козацтва: нариси у 2 т.», «Історія державної служби в Україні: у 5 т.», «Економічна історія України» у 2-х т., «Україна у Другій світовій війні: погляд з XXI століття», «Нариси історії української революції 1917-1921 pp. У 2-х кн.», «Крим: шлях крізь віки», «Феномен української національної революції 17 століття: комперативні та евристичні проекції» тощо.

Оновлений «Український історичний журнал», блискуча ідея «Історичних зошитів», рада молодих вчених та багато інших новацій завдячують появою або теперішнім становищем, безумовно, Валерієві Андрійовичу.

Ювілярові, якому виповнюється 70, хочеться від щирого серця побажати «Многая літа!» та наснаги від Бога й далі міцно тримати штурвал і впевненою рукою вести корабель Інституту історії України НАН України по морю історичної науки, оминаючи скелі та рифи...

Олександр Реєнт, Інститут історії Украӥни, Киӥв 


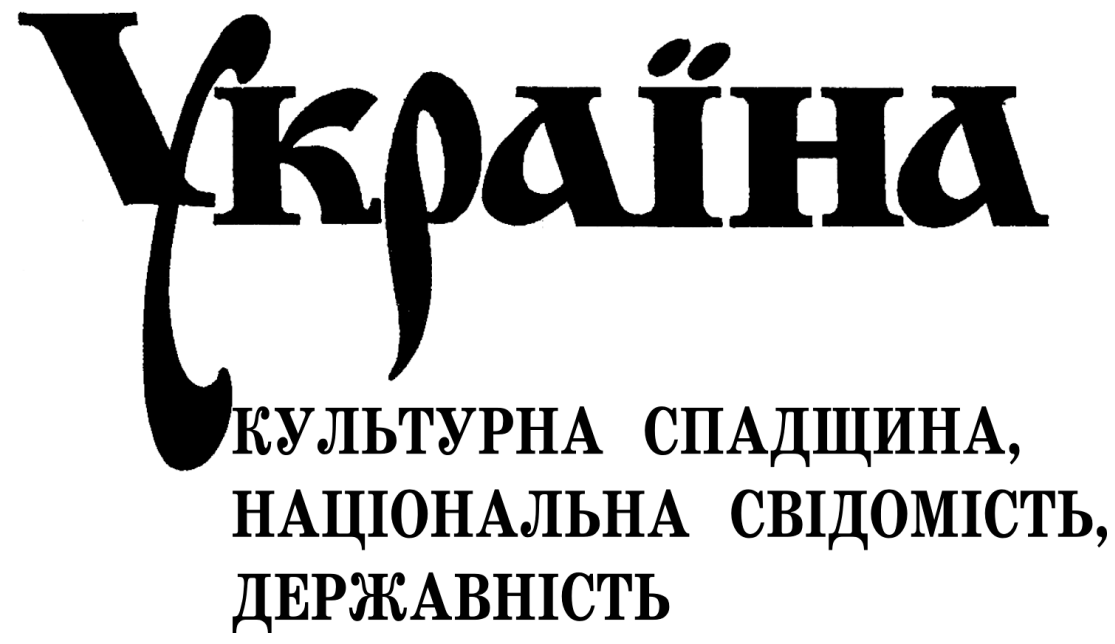

$\frac{2020}{33}$ 
Україна: культурна спадщина, національна свідомість, державність / гол. ред. Ігор Соляр; НАН України, Інститут українознавства ім. І. Крип'якевича. Львів, 2020. Вип. 33. $540 \mathrm{c}$.

Збірник об'єднує студії з історії, мовознавства та літературознавства.

Статті історичного блоку розкривають актуальні проблеми історії України, а також містять розвідки про відомих людей та їх значення у формуванні української державності.

Мовознавчі студії репрезентують українсько-угорську наукову співпрацю, аналіз мовних явищ за матеріалами пам'яток XVI-XVIII ст. та за діалектними джерелами, а також дослідження проблеми інтеграції науково-технічного прогресу (психолінгвістичний аспект).

Дослідження з літературознавства зосереджені довкола аналізу підручників з української літератури XIX століття в університетській системі, особливостей зображення подій Другої світової війни у прозі Росії, США й Угорщини XX століття, а також дослідження поезії - віршів Шевченка та урбаністичних віршів Георга Гайма та Богдана Ігоря Антонича.

Ukraine: Cultural Heritage, National Consciousness, Statehood / Ed. Ihor Soliar; NAS of Ukraine, I. Krypiakevych Institute of Ukrainian Studies. Lviv, 2020. Vol. 33. 540 p.

The collection unites studies in history, linguistics, and literary studies.

Articles of the historical section reveal current problems in Ukraine's history and contain research about famous people and their importance in forming Ukrainian statehood.

Linguistic studies represent Ukrainian-Hungarian scientific cooperation, analysis of linguistic phenomena based on the materials of the 16th-18th centuries and dialect sources, and research on the problem of integration of scientific and technological progress (psycholinguistic aspect).

Research on literary studies focuses on the analysis of textbooks on Ukrainian literature of the 19th century in the university system, the features of the events of World War II in the prose of Russia, the USA, and Hungary of the 20th century, as well as a study of poetry - poems by Shevchenko and urban poems by George Heim and Bohdan Ihor Antonych.

Рекомендувала до друку вчена рада

Інституту українознавства ім. І. Крип’якевича НАН України

(протокол № 9 від 03.12.2020 р.)

ГОЛОВНИЙ РЕДАКТОР

Соляр Ігор Ярославович, д.і.н., проф. (Україна)

ЗАСТУПНИК ГОЛОВНОГО РЕДАКТОРА

Романюк Михайло Васильович, к.і.н. (Україна)

РЕДАКЦІЙНА КОЛЕГІЯ:

Акіллі Алессандро (Achilli Alessandro), $\mathrm{PhD}$ (Australia)

Борчук Степан Миколайович, д.і.н., проф. (Україна)

Газдаг Вільмош (Gazdag Vilmos), $\mathrm{PhD}$ (Україна)

Даниленко Андрій (Danylenko Andriy), PhD, prof. (США)

Золтан Андраш (Zoltán András), dr hab., prof. (Угорщина)

Литвин Микола Романович, д.і.н., проф. (Україна)

Мозер Міхаель (Moser Michael), dr hab., prof. (Австрія)

Муравський Олег Іванович, к.і.н., с.н.с. (Україна)

Надрага Марта Степанівна, к.і.н., с.д. (Україна)

Пастух Тарас Васильович, д.філол.н., доц. (Україна)

Рембішевська Дорота Кристина (Rembiszewska Dorota Krystyna), dr hab., prof. (Польща)

Ситник Олександр Степанович, д.і.н., проф. (Україна)

Ястремська Тетяна Олександрівна, к.філол.н., с.н.с. (Україна)

ISSN 2223-1196

(C) Інститут українознавства ім. І. Крип'якевича НАН України, 2020 


\section{MICT}

\section{ІСТОРИЧНІ СТУДІї}

Актуальні питання української історії ..................... 3

Паршин Ілля. Маловідома згадка про грамоту Луцького єпископа від 1319 року . . . . . . . . . . . . . . . . . . . . . . 3

Войтович Леонтій. Стільсько: між фактами і вигадками . . . . . . . . 13

Пашук Володимир. Греко-католицьке духовенство - важливий соціальний чинник формування товариства «Просвіта» . . . . . . . . . . . 38

Кондратюк Костянтин, Коцюмбас Ореста. Академічна гімназія

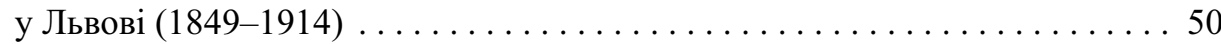

Руда Оксана. Роль політичної партії «Мізрахі» в розвитку єврейського приватного шкільництва у міжвоєнній Польщі . . . . . . . . . . 69

Chotary Juriy. Ilona Zrínyi, the symbol of freedom and courage . . . . . . . . 81 Пагіря Олександр. Від співпраці до ворожнечі: протистояння Карпатської Січі та чехословацьких органів безпеки на зламі (1938-1939) . . . . . . 90

Ільницький Василь, Батюк Тарас. Боротьба радянських репресивнокаральних органів проти підрозділів тактичного відтинку 22 «Чорний ліс» (1946-1947) . . . . . . . . . . . . . . . . . . . . . . . . . .111

Артимишин Юлія. «Закерзоння» як концепт: лінія-кордонтерен-втрачений регіон?

Боднар Галина. «Постійно відчували цензуру і відповідну планку над собою»: Львівський університет імені Івана Франка в 1970-х середині 1980-х років (структура, викладачі, кадрова політика) . . . . . . 157

Піх Олег. Геополітичні розбіжності як чинник відносин Польщі та Pociï (1994-2004)

Артимишин Павло. Харківські угоди 2010 року: візії політичних, медійних та експертних середовищ в Україні ................... 194

Krasivskyi Orest, Pidberezhnyk Nadiia. Problems of nation-building processes in Ukraine at the present stage . . . . . . . . . . . . . . . . . 214

Попко Сергій. Військово-політична співпраця України з НАТО: особливості імплементації програм співробітництва (кінець XX початок ХХІ століття). . . . . . . . . . . . . . . . . . . . . 222

Матіїв Юлія. Соціальна політика в дискурсі політичних партій на позачергових виборах до Верховної Ради у 2014 році. . . . . . . . . . . 234

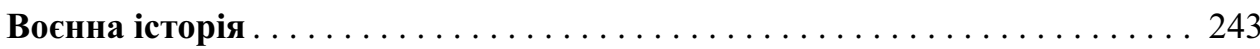

Підшибякін Сергій. Іловайська трагедія 2014 року в дискурсі української громадської думки 
Полтавець Юрій. Особливості навчального процесу

в Національній академії сухопутних військ імені гетьмана Петра Сагайдачного на сучасному етапі . . . . . . . . . . . . 260

Постаті ......................................... 270

Патер Іван. Іван Пулюй - український патріот, політик, державник . . . . . . 270

Сова Андрій. Освітньо-виховна діяльність Івана Боберського в Канаді. . . . . 294

Каменцев Денис. Публіцистична діяльність Володимира Сальського . . . . . 306

Галів Микола, Огар Анна. «Член ОУН» Варвара Степанівна Журбенко:

доля репресованої вчительки (за матеріалами архівно-

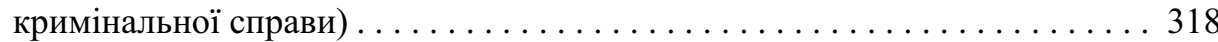

Кравець Наталія. Архівно-слідча справа Василя Проходи

як історичне джерело . . . . . . . . . . . . . . . . . . . . . . . . . 331

Костишин Роман. Громадсько-політична діяльність

Володимира Кохана в 1920-1960-х роках . . . . . . . . . . . . . . . . . . . . . 342

Романюк Михайло. Життєвий шлях Лицаря Срібного хреста

заслуги УПА Івана Червака («Дністрового»). . . . . . . . . . . . . . . . . . . 352

\section{МОВОЗНАВСТВО}

Барань Єлизавета, Барань Адальберт. Внесок Іштвана Удварі

в реабілітацію наукової спадщини Антонія Годинки . . . . . . . . . . . . . . . . 364

Осінчук Юрій. Церковнослов’ янські запозичення в лексичній системі

української мови XVI-XVII століть . . . . . . . . . . . . . . . . . . . . . . . 379

Ястремська Тетяна. Картина світу і концепт:

проблема (пере)осмислення. . . . . . . . . . . . . . . . . . . . . . . . . . . . . . . 394

Мех Наталія, Мех Олег. Інформаційно-техногенний фактор і людина:

психолінгвістичний аспект . . . . . . . . . . . . . . . . . . . . . .411

\section{ЛІТЕРАТУРОЗНАВСТВО}

Генц Адріана. Історія літератури чи філологічні студії: підручники

з української літератури ХІХ століття в університетській системі . . . . . . 422

Барань Адальберт. Особливості зображення подій Другої світової війни

у прозі Росії, США й Угорщини ХХ століття (за романами Василя

Гроссмана «Життя і доля», Джеймса Джонса «Віднині і повік»,

Імре Кертеса «Знедоленість») . . . . . . . . . . . . . . . . . . . . . . . 433

Шкраб'юк Петро. У житті й боротьбі - разом (чотири сильветки про незвичайних жінок України) . . . . . . . . . . . . . . . . . . . . . 448

Пастух Тарас. Шляхи рецепції віршів Шевченка . . . . . . . . . . . . . . . . 465

Гаврилів Тимофій. Місто в модерністичній поезії. Урбаністичні вірші

Георга Гайма та Богдана Ігоря Антонича . . . . . . . . . . . . . . . . . . . . . . . . . . . 480 


\section{ОГЛЯДИ ТА РЕЦЕНЗІї}

Мочернюк Наталія. [Рец.]: «Живий живе гадає!»: творча спадщина і чин Івана Іванця $з$ погляду XXI століття [на кн.]: Іван Іванець (1893-1946). Стрілецькі мемуари, творча спадщина / Упоряд. А. Яців і Р. Яців; вст. сл.: П. Гринчишин; наук. ред. і авт. вст. ст. д.і.н. М. Литвин. Львів, 2019. 476 с.: іл................................ 494

Голик Роман. [Рец.]: Львівська Ставропігія XVIII - початку XX століття: консервативна організація перед викликами модерності [на кн.]: Киричук О., Орлевич I. Львівський Ставропігійський інститут (1788-1914). Роль у суспільно-політичному, культурному та релігійному житті українців Галичини / НАН України, Ін-т українознавства ім. І. Крип'якевича; Львівський музей історії релігії. Львів: Логос, 2018. 288 с............. . 499

Тараніна Богдана. [Рец. на кн.]: Максим Яременко. Перед викликами уніфікації та дисциплінування: Київська православна митрополія у XVIII столітті. Львів: Вид-во УКУ, 2017. 272 с. (Серія «Киӥвське християнство», т. 4)................................ 503

Приступа Євген. [Рец. на]: Сова А. Іван Боберський: суспільно-культурна, військово-політична та освітньо-виховна діяльність: монографія; Інститут українознавства імені Івана Крип'якевича НАН України; Львівський державний університет фізичної культури імені Івана Боберського; Центр незалежних історичних студій. Львів, 2019. 512 с. . . . . 512 Міщанин Василь. [Рец. на]: Вегеш М.М., Віднянський С.В. Августин Волошин - «батько карпатоукраїнського народу». Київ: Парлам. вид-во, 2020. 472 с. + Іл., ім. пок. . . . . . . . . . . . . . . . . . . . . . . . . . . . 516

Голик Роман. [Рец.]: Освіта для нації: нова праця про міжвоєнну Галичину [на кн.]: Руда О. Національно-освітня політика урядів Польщі щодо населення Галичини в 20-30-х роках XX століття: реалізація та рецепції: монографія / Національна академія наук України, Інститут українознавства ім. І. Крип'якевича. Львів, 2019. 802 с. . . . . . 526

ЮВІЛЕї

Реєнт Олександр. Honeste vivere, alterum non laedere, suum cuique tribuere . . 530 Ястремська Тетяна. Слово про Вчителя: до ювілею Павла Юхимовича Гриценка. . . . . . . . . . . . . . . . . . . . . 533 